\title{
Petrol Fiyat Değişimlerinin BİST Endeks Getirileri Üzerindeki Etkisinin Analizi
}

\author{
Aziza SYZDYKOVA ORALBAYKIZI ${ }^{l}$
}

\section{Özet}

Petrol en önemli enerji kaynağı olmasından dolayı dünyadaki bütün ülkeler için önem arz eder. Dünyada petrol rezervleri eşit dağılmamıştır, birkaç ülke önemli petrol ihracatçısı iken diğer kalan ülkeler petrolü ithal etmektedir. Dolayısıyla hem petrol ihraç eden hem de petrol ithal eden ülkeler petrol fiyatları ile yakından ilgilenmek zorundadırlar. Petrol ihtiyacının yaklaşı \% 90 'dan fazlasını ithal eden Türkiye için petrol fiyatlarındaki değişimin makroekonomik etkilerinin araştırılması son derece önemlidir. Petrol fiyatları ve Türkiye'deki makroekonomik değişkenler arasındaki etkileşimi araştıran çok sayıda çalışma bulunmaktadır.

Bu çalışmada petrol fiyatlarındaki değişimlerin BİST 100 ulusal endeksi ve petrol ile yakından ilişkisi bulunan 3 adet sektörel endeks (XULAS, XKMYA ve XUSIN) getirileri üzerindeki etkileri araştırılmıştır. Çalışma Mayıs 2001 - Nisan 2017 dönemine ait aylık verileri kapsamakta olup, söz konusu ilişki VAR yöntemine dayalı etki tepki fonksiyonları ve varyans ayrıştırması kapsamında analiz edilmiştir. Bulgulara göre petrol fiyat değişimlerinin etkisi sektörlere göre değişmektedir.

Anahtar Kelimeler: Petrol Fiyatları, BIST 100, Hisse Senedi Getirileri, VAR analizi

Jel Kodları: F30, F65, G12, G15

\section{Analysis of the Effect of Oil Price Changes on the BIST Index Returns}

\begin{abstract}
As oil is the most important energy source, it is important for all countries in the world. Oil reserves in the world are not evenly distributed, the remaining countries import oil, while a few countries are major oil exporters. Therefore, both oil exporters and oil importers countries have to deal with oil prices closely. For Turkey which imports more than $90 \%$ of its oil needs, being investigated the effect of changes in oil prices on the stock market is extremely important for investors and policymakers.

In this study, the effects of the changes in oil prices on the BIST 100 national index and the yields of three sectoral indices (XULAS, XKMYA and XUSIN) closely related to oil were investigated. The study includes monthly datas from May 2001 - April 2017. The relationship was analyzed in terms of impact-response functions and variance decomposition based on the VAR method. According to findings, the effect of changes in oil prices depends on the sectors.
\end{abstract}

Keywords: Oil Prices, ISE100, Stock Returns, VAR analysis

Jel Codes: F30, F65, G12, G15

1 Dr., Hoca Ahmet Yesevi Uluslararası Türk-Kazak Üniversitesi, Sosyal Bilimler Fakültesi, Ekonomi ve Finans Bölümü, azizayesevi@gmail.com 


\section{Giriş}

Petrol önemli bir enerji kaynağı olup, imalat sürecinde kullanılan temel hammaddedir. Dolayısıyla dünyadaki tüm ülkelerin ekonomileri doğrudan veya dolaylı olarak petrole bağımlıdır. Ülkeler enerji bakımından petrole bağımlı oldukları kadar petrol fiyatları da tüm ekonomiler için önem arz etmektedir.

Dünyada enerji kaynakları arasında petrolün tüketim oranı \%33,27’yi oluşturmaktadır. Dünya petrol tüketimi 2017 yllında 96,55 milyon varile ulaşırken, dünya petrol üretimi 92,15 milyon varil/gün olmuştur (BP 2018). Petrol fiyatlarında yıllar itibariyle dalgalanmalar yaşanmaktadır; örneğin, 2008 yılında tarihi zirve yaparak varil başına 132 dolar olan petrol fiyatı Ocak 2016 tarihinde yaklaş1k \%77'lik bir düşüşle 30 dolara kadar gerilemiştir. Mayıs 2018 tarihinde petrolün varil fiyatı ortalama 75 dolardır (Uluslararası Enerji Ajans1, 2018).

Petrol fiyatlarındaki ilk önemli şok 1973 yılında OPEC'in uyguladığ 1 ambargo sonucunda meydana gelmiştir. Söz konusu ilk petrol krizinden sonra petrol fiyatlarındaki değişim ile makroekonomik sistem arasındaki ilişki araştırılmaya başlamıştır (Hamilton, 1983; Burbidge ve Harrison 1984; Gisser ve Goodwin,1986 vs.). Bu konuda öncü çalışmalardan biri Hamilton (1983)'e ait olup, yazar çalışmasında petrol fiyatlarındaki değişimin Amerikan ekonomisinde resesyona yol açtığı sonucunu savunmuştur. Bu çalışmanın ardından petrol fiyatları ve makroekonomik değişkenler arasındaki ilişkiler çeşitli ülke ve ülke grupları için farklı yöntemlerle analiz edilmiştir. Bununla birlikte özellikle son yıllarda fiyatlardaki değişimlerin hisse senedi piyasa fiyatı ve getirileri üzerinde yarattığı etkileri inceleyen çalışma sayısında da artış görülmektedir.

Literatürde, petrol fiyatlarındaki değişimlerin çeşitli kanallar üzerinden hisse senedi fiyatları üzerinde etkili olabileceği ifade edilmektedir. Örneğin, petrol fiyatlarındaki risk ve belirsizliğin artması küresel ekonomik büyüme oranları üzerinde negatif etkiler doğurabilmektedir, bu da hisse senedi endekslerinde düşüşlere yol açabilmektedir (Basher ve Sadorsky, 2006: 225; Dagher ve El Hariri, 2013: 366). Petrol fiyatlarındaki artışlar enflasyon oranlarında da artışlara yol açabilmektedir. Enflasyon oranlarındaki artışlar ise merkez bankalarını faiz oranlarını artırmaya itebilmektedir. $\mathrm{Bu}$ durum hisse senetlerinin değerlenmesinde kullanılan iskonto faktörlerinin artmasına yol açarak nakit akışlarının bugünkü değerlerinin azalmasına sebep olabilmektedir (Basher vd., 2012: 229; Narayan ve Narayan, 2010: 357). Ayrıca, petrol fiyatlarındaki artışlar şirketlerin üretim maliyetlerinde artışlara sebep olup, bunun sonucunda azalan şirket karları ise hisse senedi piyasalarında düşüşlere yol açabilmektedir (Narayan ve Narayan, 2010: 357).

Literatürdeki çalışmaların çoğunun petrol fiyatları ile gösterge hisse senedi endeksleri arasındaki ilişkiye odaklanması nedeniyle sektörel endeksleri dikkate alan çalışma sayısının oldukça az olduğu görülmektedir (Li vd., 2012: 1951). Bu çalışmada petrol fiyatlarının sadece BİST 100 endeksi üzerindeki etkisi değil aynı zamanda petrol ile yakından ilişkili olan Ulaştırma, Sınai ve 
Kimya gibi sektörel endeksler üzerindeki etkisi de incelenmiştir. Bu kapsamda dikkat edilmesi gereken nokta; Türkiye petrol ihtiyacının yaklaşık \%90'ını ithalat ile karşılayan ülke olduğundan Türkiye'nin petrol fiyatları üzerinde herhangi bir etkisi bulunmamaktadır. Aksine petrol fiyatlarındaki dalgalanmalara karşılık tamamen korunmasız durumdadır. Bu çalışmada öncelikle petrol fiyatları ile hisse senedi getirileri arasındaki ilişkiyi analiz eden çalışmalara yer verilmiştir. Daha sonra çalışmada kullanılan veri seti ve yöntem açıklanarak, analiz ve bulgulara göre model sonuçlarına değinilmiştir. Çalışma sonuç kısmi ile son bulmuştur.

\section{Literatür Taraması}

Petrol fiyatlarının hisse senedi piyasaları üzerindeki etkilerini araştırmaya yönelik literatürde çok sayıda çalışma mevcuttur. Çalışmaların büyük bir bölümü söz konusu ilişkiyi gelişmiş ülke grupları için araştırmıştır. Gelişmekte olan ülkeler için yapılmış çalışmaların sayısı son dönemlerde artmaya başlamıştır. Bununla birlikte petrol fiyatlarının sektörler üzerindeki etkilerine yönelik göreceli olarak az sayıda çalışma yapılmıştır.

Petrol fiyatları ve hisse senedi getirileri arasındaki ilişkiyi inceleyen ilk çalışmalardan Jones ve Kaul'e aittir (Abdioğlu ve Değirmenci, 2014). Jones ve Kaul (1996), 1970-1991 tarihleri arasında çeyreklik verileri kullanarak ABD, Kanada, Japonya ve İngiltere için değişkenler arasındaki ilişkiyi incelemiştir. Çalışma sonucunda petrol fiyatlarındaki değişimin ABD, Kanada, Japonya ve İngiltere'de savaş sonrası dönemde çıktı ve reel hisse senedi getirileri üzerinde olumsuz etkileri söz konusudur. Ayrıca yazarlar hisse senedi piyasalarının petrol fiyatlarındaki değişime verdikleri tepkiyi, şimdiki ve gelecekteki reel nakit akımlarının değişimi ile açıklanacağını söylemişlerdir.

Bir diğer çalışma Huang ve diğerleri (1996) tarafindan yapılmış olup, söz konusu çalışmada New York Mercantile Exchange (NYMEX)'da işlem gören vadeli petrol fiyatları ile ABD hisse senedi getirileri arasındaki ilişki VAR modeli kullanılarak araştırılmıştır. Günlük verilerin kullanıldığı çalışmada vadeli petrol fiyatlarından 3 büyük petrol şirketlerinin (Chevron, Exxon ve Mobil) hisse senedi getirilerine doğru anlamlı bir Granger nedensellik tespit edilirken vadeli petrol fiyatları ve S\&P endeksi arasında herhangi bir ilişki bulunamamıştır.

Faff ve Brailsford (1999) çalışmasında iki faktörlü Arbitraj fiyatlama modeli ile Avustralya'daki 24 sektörün hisse senedi getirilerinin petrol fiyatlarına karşı duyarlılığını incelemişlerdir. Çalışmanın bulgularına göre petrol fiyatları ile petrol ve gaz sektörü, çeşitlendirilmiş ürün sektörleri arasında anlamlı ve pozitif bir ilişki varken, petrol fiyatları ile kağıt ve ambalaj, ulaştırma ve bankacılık sektörleri arasında ise anlamlı ve negatif ilişki gözlenmiştir.

Nandha ve Faff (2008), Nisan 1983-Eylül 2005 döneminde petrol fiyat şoklarının 35 küresel endüstri endeksi üzerindeki etkisini analiz etmişlerdir. Çalışma sonucunda madencilik, petrol ve gaz sektörleri dışındaki tüm sektörlerde petrol fiyatlarındaki değişimin hisse getirilerinde negatif bir etkiye sahip olduğunu tespit etmişlerdir. Ayrıca yazarlar çeşitlendirme etkisinden yararlanmak isteyen 
yatırımcıların petrol ile pozitif korelasyona sahip varlık sınıfını mutlaka portföylerine katmaları ya da petrol türevleri kullanarak sentetik korunma yöntemleri geliştirmeleri gerektiğini vurgulamışlardır.

Narayan ve Narayan (2010) çalışmasında Vietnam için 28 Temmuz 2000-16 Haziran 2008 dönemine ait günlük verileri kullanarak Johansen Eş-Bütünleşme yöntemi ile petrol fiyatları, hisse senedi fiyatları ve döviz kuru arasındaki eşbütünleşik bir ilişki olup olmadığını araştırmışlardır. Analiz sonuçlarına göre, uzun dönemde petrol fiyatları, hisse senedi fiyatları ve döviz kuru arasında ilişki bulunmuştur. Ayrıca petrol fiyatlarının hisse senedi fiyatlarına etkisinin pozitif olduğu ortaya çıkmıştır.

Arouri (2011) çalışmasında petrol fiyat değişimlerinin 18 Avrupa ülkesinin 1 Ocak 1998- 30 Haziran 2010 dönemine ait haftalık verileri en büyük şirketlerinin oluşturduğu 15 sektör endekslerine etkisini ayrı ayrı analiz etmiştir. VAR modelinin kullanıldığı çalışma sonuçlarına göre, petrol fiyat değişimleri ile birçok Avrupa ülkesinin sermaye piyasası arasında ilişkiler tespit edilmiştir. Petrol fiyat artışlarının etkisi otomobil sektör hisseleri için negatif ve zayıftır. Petrol fiyat değişimleri ile petrolü yoğun kullanan bir sektör olmayan finans sektörü arasında güçlü ve negatif bir ilişki vardır. Yemeiçme sektörünü petrol fiyat artışları negatif etkilemektedir fakat yeme içme sektörü petrol ve petrol ile ilgili ürünleri yiyecek üretiminde kullandıkları için bu bulgu şaşırtıcıdır. Petrol fiyat değişimleri ile Petrol ve Gaz sektörü arasında güçlü ve pozitif ilişki bulunmuştur. Petrol fiyat değişimleri kısa dönemde, Kimya ve Maden sektörünü ve Hizmet sektörünü pozitif etkilerken sağlik sektörünü ve Teknoloji-Telekomünikasyon sektörlerini de negatif olarak etkilemektedir. Ayrıca, Arouri (2011), petrol fiyatlarından sanayi sektör hisse senetlerine zayıf bir nedensellik tespit etmiş ve Altyapı sektörüne petrol fiyat değişimlerinin zayıf bir etkisi olduğunu bulmuştur.

Li ve Wen (2012) 1997-2012 dönemini kapsayan çalışmalarında regresyon analizini kullanarak seçilmiş bazı makroekonomik değişkenler (tüketici ve üretici fiyat endeksi, faiz Oranları, sanayi üretimi büyüme oranı ve ham petrol fiyatları) ile Borsa Sanayi Fiyat Endeksi arasındaki ilişkiyi analiz etmişlerdir. Çalışma sonucunda üretici fiyat endeksi ve faiz oranlarının Borsa Sanayi Fiyat Endeksi ile negatif, tüketici fiyat endeksi, sanayi üretimi büyüme oranı ve petrol fiyatları ile pozitif ilişkiye sahip olduğu sonucuna ulaşılmıştır.

Degiannakis vd., (2013) çalışmalarında Ocak 1992-Aralık 2010 döneminde zamanla değişen çok değişkenli heteroskedastik bir çerçeve kullanarak petrol fiyat getirileri ile 10 Avrupa sanayi sektörü endeks getirileri arasındaki ilişkiyi incelemişlerdir. Çalışma sonucunda sektör endeksleri ile petrol fiyatları arasındaki ilişkinin zaman içerisinde değiştiğini ve ilişkilerin endüstrilere özgü olduğunu belirlemişlerdir. Ayrıca arz yönlü petrol fiyat şoklarının düşük-orta derecede pozitif korelasyona yol açarken, talep yönlü petrol fiyat şoklarının korelasyon seviyelerinde pozitif veya negatif önemli değişmelere yol açtığını, bununla birlikte petrol fiyat şokunun kaynağı ve endüstri 
türünün, endüstri sektör getirileri ile petrol fiyatları arasındaki korelasyonun önemli belirleyicileri olduklarını tespit etmişlerdir.

Ayrıca bu konuda yapılmış çok sayıda ulusal çalışma bulunmaktadır. Güler vd. (2010) çalışmasında 10 Temmuz 2010-10 Ağustos 2010 dönemine ait verileri kullanarak petrol fiyatlarındaki değişimlerin BİST’te işlem gören enerji sektörünün hisse senedi fiyatları üzerindeki etkisini incelemişlerdir. Eşbütünleşme ve Granger nedensellik testlerinin kullanıldığ 1 çalışma sonucunda petrol fiyatları ile enerji sektörü hisse senedi fiyatları arasında uzun dönemli bir ilişki olduğunu ve Brent petrol fiyatındaki değişimin, BİST elektrik endeksinin fiyat değişimlerinin bir nedeni olduğunu tespit etmişlerdir.

Toraman vd., (2011) çalışmasında 02.01.2009-15.02.2011 dönemde eşbütünleşme testlerini kısa dönem ve vektör hata düzeltme modelini (VECM) kullanarak petrol fiyatları ile İstanbul Menkul Kıymetler Borsası 100 Endeksi, İstanbul Menkul Kıymetler Borsası (IMKB) Hizmetler Endeksi, İMKB Sanayi Endeksi ve İMKB Teknoloji Endeksi arasındaki ilişkiyi test etmişlerdir. Çalışma petrol fiyatlarındaki değişimin en fazla İMKB Sanayi Endeksinde meydana gelen değişimi açıkladığı, daha sonra ise sirasıyla İMKB 100 Endeksi, İMKB Hizmetler Endeksi ve İMKB Teknoloji Endekslerinde meydana gelen değişimleri açıkladığı sonucuna ulaşılmıştır.

Öztürk vd., (2013) çalışmasında 02.01.1997-31.12.2009 döneminde yapısal kırılmalı birim kök ile eşbütünleşme testlerini kullanarak petrol ve doğalgaz fiyatları ile BíST imalat sektörü ve kimya-petrol-plastik sektörü endeksleri arasındaki ilişkiyi incelemişlerdir. Çalışma sonucunda kırılmaları dikkate alan test sonuçlarına göre petrol fiyatları ile BİST imalat sanayi endeksi ve kimyapetrol-plastik sektörü endeksi arasında bir eşbütünleşme olduğunu, petrol fiyatlarının söz konusu endeksleri pozitif etkilediği dinamik en küçük kareler metodu ile tespit edilmiştir.

Akgün vd., (2013) çalışmasında Ocak 2000-Nisan 2013 döneminde Johansen eşbütünleşme testini kullanarak altın ve petrol fiyatlarındaki değişmelerin BİST 100 üzerindeki etkisini incelemişlerdir. Çalışma sonucunda BİST 100 endeksi ile petrol fiyatları arasında pozitif bir ilişki olduğunu belirlemişlerdir.

Yıldırım vd., (2014) yaptıkları çalışmada Ocak 1991 ve Kasım 2013 dönemleri arasındaki verileri kullanarak petrol ve doğalgaz fiyatları ile Borsa İstanbul Sanayi Endeksi hisse senetleri arasındaki ilişkiyi test etmek istemişlerdir. Çalışmalarında uluslararası piyasalardaki petrol ve doğalgaz fiyatlarının Borsa İstanbul'da işlem gören sanayi şirketlerinin hisse senedi fiyatları üzerinde etkili olduğu sonucuna varmışlardır. Bu çalışmada nedensellik ilişkinin tespit edilebilmesi için aylık veriler kullanılmış ve çalışma sonucunda uluslararası piyasalardaki ham petrol ve doğalgaz fiyat endeksleri ile Borsa İstanbul sınai endeksi arasında Borsa İstanbul Sanayi endeksine doğru tek yönlü uzun dönemli Granger nedensellik ilişkisi tespit etmişlerdir. 
Türkiye borsası için yapılmış çalışmalar Aşağıdaki Tablo 1'de özetlenmiştir.

Tablo 1. Türkiye Borsası İçin Yapılmış Çalışmaların Özeti

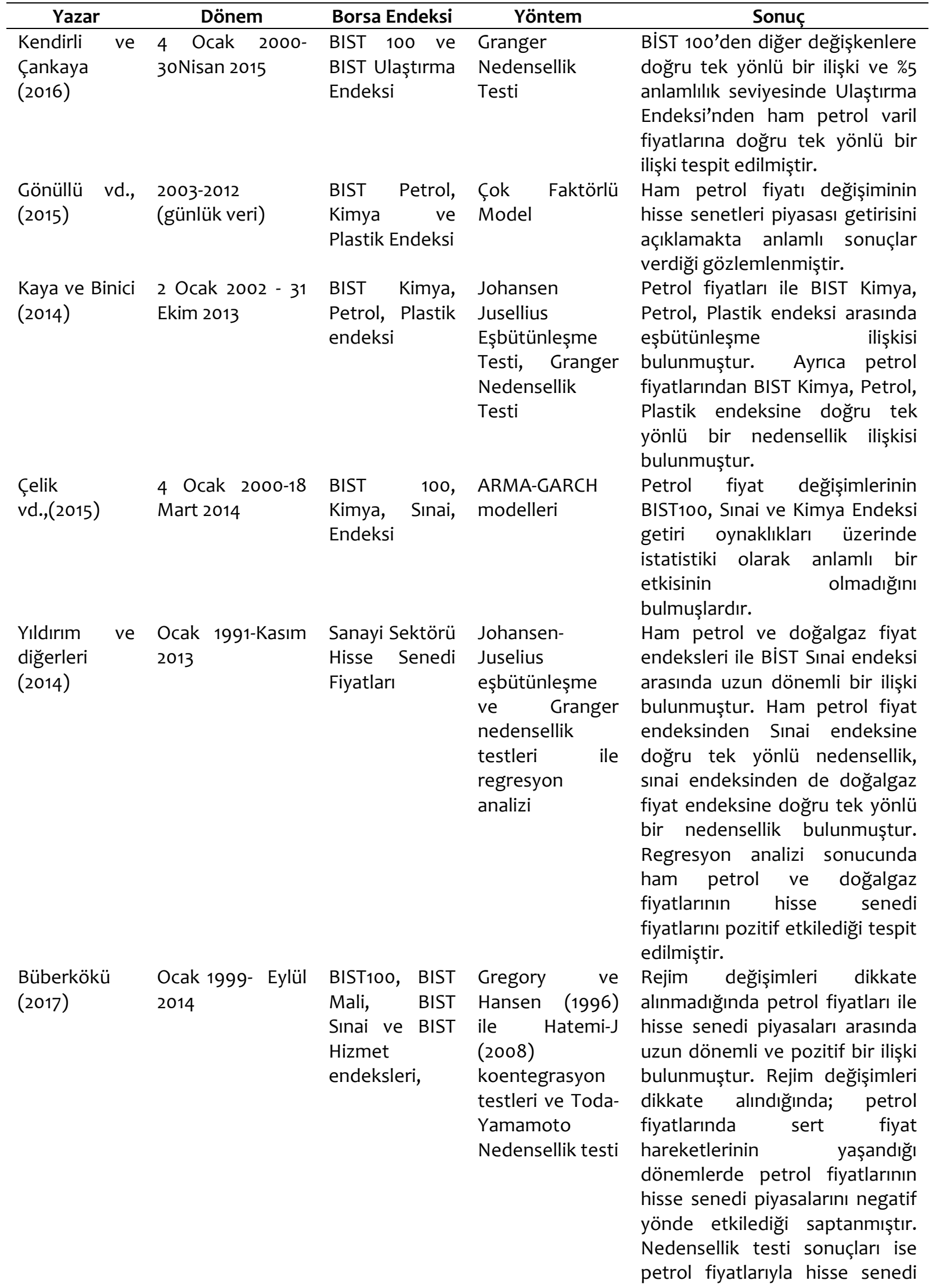




\begin{tabular}{|c|c|c|c|c|}
\hline $\begin{array}{l}\text { Güler ve Nalın } \\
\text { (2013) }\end{array}$ & $\begin{array}{l}3 \text { Şubat 1997- } \\
\text { 30Kasım2012 }\end{array}$ & $\begin{array}{l}\text { BiST 100, BIST } \\
\text { Sinai ve BiST } \\
\text { Kimya, Petrol } \\
\text { ve Plastik } \\
\text { endeksleri }\end{array}$ & $\begin{array}{l}\text { Eşbütünleşme } \\
\text { analizi ve } \\
\text { Granger } \\
\text { nedensellik testi }\end{array}$ & $\begin{array}{l}\text { göstermiştir. } \\
\text { Değişkenlerin uzun dönemde } \\
\text { birlikte hareket ettikleri, ancak } \\
\text { kısa dönemde aralarında } \\
\text { nedenselliğin olmadığı ortaya } \\
\text { çıkmıştır. }\end{array}$ \\
\hline $\begin{array}{l}\text { Güler } \\
(2010)\end{array}$ & $\begin{array}{l}\text { Temmuz 2000- } \\
\text { Ağustos } 2009\end{array}$ & $\begin{array}{l}\text { Enerji hisse } \\
\text { fiyatları, } \\
\text { elektrik } \\
\text { endeksi }\end{array}$ & $\begin{array}{l}\text { Eşbütünleşme } \\
\text { ve Granger } \\
\text { nedensellik testi }\end{array}$ & $\begin{array}{l}\text { Değişkenler uzun dönemde } \\
\text { birlikte hareket etmektedir. } \\
\text { Ayrıca Brent petrol fiyatındaki } \\
\text { değişim BisT elektrik endeksinin } \\
\text { fiyat değişimlerinin bir } \\
\text { nedenidir. }\end{array}$ \\
\hline $\begin{array}{l}\text { Kılıç vd., } \\
(2014)\end{array}$ & $\begin{array}{l}\text { Ocak 1994-Kasım } \\
2013\end{array}$ & $\begin{array}{l}\text { BiST Sanayi } \\
\text { Endeksi }\end{array}$ & $\begin{array}{l}\text { Gregory-Hansen } \\
\text { eşbütünleşme } \\
\text { testi, dinamik } \\
\text { en küçük kareler } \\
\text { (DEKK) } \\
\text { yaklaşımı }\end{array}$ & $\begin{array}{l}\text { Ham petrol fiyatları ile sanayi } \\
\text { fiyat endeksi arasında uzun } \\
\text { dönemli ilişki olduğu, ham petrol } \\
\text { fiyatlarındaki artışın sanayi fiyat } \\
\text { endeksini artırdığı tespit } \\
\text { edilmiştir. }\end{array}$ \\
\hline $\begin{array}{l}\text { Abdioğlu ve } \\
\text { Değirmenci } \\
\text { (2014) }\end{array}$ & $\begin{array}{l}\text { 2005-2013 } \\
\text { (günlük veri) }\end{array}$ & $\begin{array}{l}\text { BisT tüm, } \\
\text { Teknoloji, } \\
\text { Sınai, Mali ve } \\
\text { Hizmetler } \\
\text { endekslerine } \\
\text { ait alt } \\
\text { sektörler }\end{array}$ & $\begin{array}{l}\text { Granger } \\
\text { nedensellik testi }\end{array}$ & $\begin{array}{l}\text { Granger nedensellik testi } \\
\text { sonuçlarına göre alt sektörler } \\
\text { için hisse senedi fiyatlarından } \\
\text { petrol fiyatlarına doğru bir } \\
\text { nedensellik ilișkisi olduğu tespit } \\
\text { edilmiştir. }\end{array}$ \\
\hline
\end{tabular}

\section{Veri Seti, Model ve Yöntem}

\subsection{Araştırmada Kullanılan Model ve Değişsenler}

Petrol fiyatlarının yüksek seyretmesi, petrol ithal eden ülke olan Türkiye açısından cari açığın artması, enflasyonun yükselmesi, büyümenin ve yatırımların düşmesi gibi sorunları ortaya çıkarmaktadır. Teorik olarak bu tür sorunlar bir ekonomide borsalara olumsuz yansıyacak ve borsada işlem gören hisse senetlerinin fiyatlarını düşürecektir. Bu çalışmanın amacı; petrol fiyat değişimlerinin BİST 100 Ulusal endeksi ve BİST Sınai, BİST Ulaştırma, BİST Kimya gibi petrolü hammadde olarak üretim sürecinde kullanan dolayısıyla petrolle yakından ilişkisi bulunan sektörel endeksler üzerine etkilerini tespit etmektir. Bu amaçla çalışmada VAR analizi yapılacak olup, kullanılan veri seti tüm değişkenler için ortak olması açısından Mayıs 2001 ve Nisan 2017 dönemi seçilmiştir. Çalışmada kullanılan değişkenler ve kaynakları Tablo 2'de sunulmuştur. 
Tablo 2. Değişkenler ve Kaynakları

\begin{tabular}{|c|c|c|c|}
\hline Değișkenler & & Açıklama & Kaynaklar \\
\hline \multirow{4}{*}{$\begin{array}{l}\text { Bağımlı } \\
\text { Değişkenler }\end{array}$} & bist 100 & BisT 100 endeks getirisi & Endekslere ait kapanış fiyatları \\
\hline & xulas & BisT Ulaştırma Endeksi getirisi & veri tabanından \\
\hline & $x k m y a$ & BisT Kimya Endeksi getirisi & alınmıştır. \\
\hline & $x u \sin$ & BisT Sınai endeksi getirisi & \\
\hline \multirow{5}{*}{$\begin{array}{l}\text { Bağımsız } \\
\text { değişkenler }\end{array}$} & $o p$ & $\begin{array}{l}\text { Brent petrol fiyatının yüzde } \\
\text { değişimi (petrol getirisi) }\end{array}$ & $\begin{array}{l}\text { U.S. Energy Information } \\
\text { Administration } \\
\text { https://www.eia.gov }\end{array}$ \\
\hline & $i p$ & $\begin{array}{l}\text { Sanayi üretim endeksinin } \\
\text { yüzde değişimi }(2010=100)\end{array}$ & $\begin{array}{l}\text { IMF Data, } \\
\text { http://www.imf.org/en/Data }\end{array}$ \\
\hline & cpi & $\begin{array}{l}\text { Tüketici fiyat endeksinin yüzde } \\
\text { değişimi }(2010=100)\end{array}$ & $\begin{array}{l}\text { Bank for International Settlements } \\
\text { https://www.bis.org }\end{array}$ \\
\hline & reer & $\begin{array}{l}\text { Reel efektif döviz kurunun } \\
\text { yüzde değişimi }(2010=100)\end{array}$ & $\begin{array}{l}\text { Bank for International Settlements } \\
\text { https://www.bis.org }\end{array}$ \\
\hline & ir & $\begin{array}{l}\text { Faiz oranının yüzde değişimi, ( } 3 \\
\text { aylık mevduat faizi) }\end{array}$ & TCMB istatistikleri \\
\hline
\end{tabular}

Tablo 3'te petrol ve borsa endeksi getiri serilerine ilişkin tanımlayıcı istatistiklere yer verilmiştir. Buna göre standart sapması en yüksek olup getiri açısından riskli endeksin BİST Ulaştırma endeksi olduğu görülmektedir. Çalışmaya dahil edilen dönemde en yüksek ve en düşük getiri sağlayan endeks yine BİST Ulaştırma endeksi olmuştur. Diğer üç endeks hem ortalama getiri hem de standart sapma bakımından bir birine çok yakındır. Tüm endeksler sağa çarpık olup, normal dağılmaktadır.

Tablo 3. Getiri Serilerine iliş̦kin Açıklayıcı İstatistikler

\begin{tabular}{lcccc}
\hline & BIST100 & KIMYA & SINAI & XULAS \\
\hline Ortalama & 0.015563 & 0.015949 & 0.016291 & 0.019188 \\
Medyan & 0.017336 & 0.022169 & 0.017715 & 0.009198 \\
Maximum & 0.297357 & 0.350853 & 0.292886 & 0.424183 \\
Minimum & -0.231203 & -0.243659 & -0.230355 & -0.408859 \\
Standart sapma & 0.092280 & 0.087753 & 0.080057 & 0.119410 \\
Çarpıklık & 0.130579 & 0.046097 & 0.001133 & 0.031399 \\
Basıklık & 3.721632 & 4.468766 & 4.304453 & 4.120430 \\
Jarque-Bera & 4.687106 & 17.23595 & 13.54193 & 10.02198 \\
Gözlem & 191 & 191 & 191 & 191
\end{tabular}

Yukarıdaki getiri serilerinin bağımlı değişken olduğu ve bağımsız değişkenler ile oluşturulan regresyon modeli aşağıda sunulmaktadır.

$\operatorname{rindex}_{t}=\beta_{0}+\beta_{1}$ oil $_{t}+\beta_{2} c p i_{t}+\beta_{3} i p_{t}+\beta_{4} \operatorname{reer}_{t}+\beta_{5} i r_{t}+\varepsilon_{t}$

Doğrusal regresyon modelleri; her endeks getiri serisinin bağımlı değişken, petrol fiyatı getiri serisinin ise bağımsız değişken olacak şekilde oluşturulmuştur. Modelin oluşturulmasında Tablo 4'te ayrıntıları verilmiş olan çalışmalar örnek alınmıştır. 
Tablo 4. Ampirik Çalışma İçin Örnek Modeller

\begin{tabular}{|c|c|c|}
\hline Çalışma & Yöntem & Model \\
\hline Sadorsky P. (1999) & $\begin{array}{c}\text { VAR ve Genelleştirilmiş } \\
\text { Otoregresif Koşullu } \\
\text { Değişen Varyans (GARCH) } \\
\text { modeli }\end{array}$ & $\begin{array}{l}\text { Getiri=f(sanayi üretim endeksi, faiz } \\
\text { oranları, reel petrol fiyatları, S\&P } \\
\text { endeks getirisi, enflasyon) }\end{array}$ \\
\hline $\begin{array}{l}\text { Park J.ve Ratti A.R. } \\
\qquad(2008)\end{array}$ & Çok değişkenli VAR modeli & $\begin{array}{l}\text { Getiri=f(kısa vadeli faiz oranları, } \\
\text { enflasyon, sanayi üretimi, petrol fiyat } \\
\text { şokları) }\end{array}$ \\
\hline $\begin{array}{l}\text { Kilian L. ve Park } \\
\text { Ch.(2008) }\end{array}$ & VAR modeli & $\begin{array}{l}\text { Getiri=f(dünya ham petrol üretimindeki } \\
\text { yüzde değişim, reel ham petrol fiyatı, } \\
\text { dünya reel ekonomik aktivite indeksi) }\end{array}$ \\
\hline Filis G. (2010) & $\begin{array}{l}\text { Eşbütünleşme testi, } \\
\text { Vektör hata düzeltme } \\
\text { modeli }\end{array}$ & $\begin{array}{l}\text { Getiri=f(tüketici fiyatları endeksi, sanayi } \\
\text { üretimi, petrol fiyatları) }\end{array}$ \\
\hline Le ve Chang (2011) & VAR modeli & Getiri=f(petrol fiyatları, döviz, faiz oranı) \\
\hline Li ve Wen (2012) & $\begin{array}{l}\text { Doğrusal olmayan regresyon } \\
\text { analizi }\end{array}$ & $\begin{array}{l}\text { Getiri=f(tüketici ve üretici fiyat endeksi, } \\
\text { faiz oranları, sanayi üretimi büyüme } \\
\text { oranı ve ham petrol fiyatları }\end{array}$ \\
\hline
\end{tabular}

Kaynak: Syzdykova, A. (2018: 11)

\subsection{Araştırmanın Yöntemi}

$\mathrm{Bu}$ çalışmada petrol fiyat değişimlerinin BİST 100 ulusal endeksi ve BİST Sınai, BİST Ulaştırma, BİST Kimya gibi sektörel endeksler üzerine etkilerini araştırmak için VAR analizi kullanılmıştır. VAR modeli, sistemde yer alan çok sayıda değişkenin geçmiş değerleri ile ifade edildiği ve her bir denklemin EKK( En Küçük Kareler) ile çözümlendiği bir çözüm tekniğidir. Geçmiş bilginin kullanılması ile sağlanan bu yapı, zaman serilerine dinamizm katmıştır (Bozkurt, 2007: 76).

VAR modeli, seçilen bütün değişkenleri birlikte ele alır ve bir sistem bütünlüğü içinde inceler. Ekonometrik modelin şekillendirilmesi aşamasında, belirli ve modelin oluşumuna etki eden katı bir iktisadi teorinin varlı̆ğ kabul edilmez. İktisadi teorinin öne sürdüğü kısıtlamaların, varsayımların, model tanımını bozmasına izin verilmez. Değişkenler arası ilişkiler hakkında bir ön kısıt konulmaz. Böylelikle ekonometristlerin model kurma aşamasında yapmak zorunda oldukları ön varsayımların, olumsuz etkileri büyük ölçüde ortadan kalkmaktadır. VAR modelleri öncelikle makroekonomik değişkenler arasındaki ilişkilerin incelenmesinde ve rassal şokların değişkenler sistemine olan dinamik etkisinin analizinde kullanılır. Hatta birçok iktisatçıya göre kısıtsız VAR, öngörü için klasik yapısal modellemeden daha iyi sonuç verir (Greene, 1993: 553). 
Standart bir VAR modeli şu şekilde ifade edilebilir:

$$
\begin{aligned}
& y_{t}=a_{1}+\sum_{i=1}^{p} b_{1 i} y_{t-i}+\sum_{i=1}^{p} b_{2 i} x_{t-i}+u_{1 t} \\
& x_{t}=c_{1}+\sum_{i=1}^{p} d_{1 i} y_{t-i}+\sum_{i=1}^{p} d_{2 i} x_{t-i}+u_{2 t}
\end{aligned}
$$

Yukarıdaki modelde $p$ gecikmelerin uzunluğunu, $u$ ortalaması sıfır, kendi gecikmeli değerleriyle olan kovaryansları sıfır ve varyansları sabit, normal dağılıma sahip, rassal hata terimlerini göstermektedir. Var modelinde hataların kendi gecikmeli değerleriyle ilişkisiz olması varsayımı, modele herhangi bir kısıt getirmez. Çünkü değişkenlerin gecikme uzunluğunun artırılmasıyla otokorelasyon sorununun üstesinden gelinilir (Özgen ve Güloğlu, 2004: 4-5).

VAR modelleri, öngörü amaçlı kullanılabilir. Buna karşı Sims 1980 çalışmasında VAR modellerini değişken arasındaki karşılıklı dinamik ilişkilerin araştırılması amacıyla ilk kez kullanmıştır. Bu analizlerde kullanmış olduğu iki yaklaşım vardır. Bunlar:

1. Etki tepki fonksuyonları (impulse- response)

2. Öngörü hatasının varyans ayrıstırması (variance decomposition)

VAR modeli, herhangi bir iktisat teorisinden yola çıkarak, değişkenlerin içsel-dışsal ayrımını gerektirmediği için, eşanlı denklem sistemlerinden ayrılmaktadır. Bununla birlikte, VAR modellerinde bağımlı değişkenlerin gecikmeli değerlerinin yer almasından dolayı geleceğe yönelik tahminlerin yapılması mümkün olmaktadır (Bozkurt, 2007: 154).

Var modellerinden elde edilen Etki-Tepki fonksiyonları, sıklıkla, sistemdeki değişkenlerden birisine gelen şokun, sistemdeki diğer değişkenler üzerindeki etkilerini incelemek için kullanılırlar. Başka bir ifadeyle Etki-Tepki fonksiyonları VAR modelindeki her bir değişkenin, yapısal şoklar ortaya çıktığında, bu şoklara karşı dinamik tepkisini gösterirler (Kilian, 1998). 


\section{Analiz Bulguları}

\subsection{Değişkenlere Ait Birim Kök Testi Sonuçları}

Öncelikle serilerin durağan oldukları seviyeler ADF ve PP birim kök testleri ile belirlenmiştir. Tablo 5 değişkenlere ait birim kök testi sonuçlarını göstermektedir.

Tablo 5. ADF ve PP Birim Kök Test Sonuçları

\begin{tabular}{|c|c|c|c|c|c|}
\hline \multirow{2}{*}{\multicolumn{2}{|c|}{ Değişkenler }} & \multicolumn{2}{|c|}{ ADF } & \multicolumn{2}{|c|}{ PP } \\
\hline & & t-istatistiği & p-değeri & t-istatistiği & p-değeri \\
\hline \multirow{4}{*}{ Bağımlı } & bist10o & $-14.4806(0)$ & 0.0000 & $-14 \cdot 5188$ & 0.0000 \\
\hline & xulas & $-6.8648(2)$ & 0.0000 & $-13 \cdot 3291$ & 0.0000 \\
\hline & xkmya & $-7.8252(2)$ & 0.0000 & -14.2085 & 0.0000 \\
\hline & xusin & $-14.2671(0)$ & 0.0000 & -14.2778 & 0.0000 \\
\hline \multirow{7}{*}{ Bağımsız } & op & $-6.7245(5)$ & 0.0000 & -10.7099 & 0.0000 \\
\hline & cpi & $-3.0491(11)$ & 0.1220 & -8.8935 & 0.0000 \\
\hline & $\Delta c p i$ & $-14.7113(10)$ & 0.0000 & - & - \\
\hline & ip & $-2.9233(12)$ & 0.1577 & -54.1640 & 0.0001 \\
\hline & $\Delta i p$ & $-13.2201(11)$ & 0.0000 & - & - \\
\hline & reer & $-8.8738(3)$ & 0.0000 & -10.2622 & 0.0000 \\
\hline & ir & $-19.0180(0)$ & 0.0000 & -19.0180 & 0.0000 \\
\hline
\end{tabular}

ADF regresyon eşitliği deterministik bileşenlerden sabit terim ve trend içermektedir. Parantez içindeki değerler uygun gecikme uzunluklarını göstermektedir.

ADF ve PP birim kök testi sonuçlarına göre araştırma kapsamında yer alan bağımlı değişkenlerin tamamı (bist100, xulas, xkmya, xusin) her iki teste göre seviyede durağandır. Getiri serilerine ilişkin grafikler ekte yer almaktadır. Buna karşılık bağımsız değişkenlerden petrol fiyatları, reel efektif döviz kuru ve faiz oranı değişkenleri her iki teste göre düzeyde durağandır. Fakat enflasyon ve sanayi üretim endeksi değişkenlerine ait birim kök sonuçları iki teste göre farklılık göstermektedir. ADF birim kök testi sonuçlarına göre değişkenler düzeyde birim kök içerirken, PP testine göre seviyede durağan oldukları görünmektedir. Bir sonraki aşamada VAR yönteminin uygulanması için bağımlı değişkenlerin tamamı ve bağımsız değişkenlerden petrol fiyatı $(o p)$ ve faiz oranı (ir) değişkenleri düzey değerleriyle, enflasyon (cpi) ve sanayi üretim endeksi (ip) değişkenlerinin birinci sıra farkları ${ }^{2}$ alındıktan sonra modelde yer alması gerekmektedir.

\subsection{VAR Analizi Sonuçları}

Var modeline geçmeden önce modele ait gecikmenin belirlenmesi gerekmektedir. Gecikme değerlerinin tayin edilmesinde kullanılan en önemli yöntemler Akaike Bilgi Kriteri (AIC) ile Schwarz Bilgi Kriteri (SIC) değeri yöntemidir. VAR modeli için maksimum gecikme uzunluğu 12 olmak üzere uygun gecikme yapısı AIC'e göre 4 olarak belirlenmiştir.

\footnotetext{
${ }^{2} \mathrm{ADF}$ ve PP testlerinden analizlerde en çok tercih edilen test ADF testi olduğundan sonucuna karar verilip, birinci sıra farkı alınmıştır.
} 


\subsubsection{Etki Tepki Fonksiyonları}

Şekil 1'de analize dahil edilen bağımlı değişkenler BİST 100, XULAS, XUSIN ve XKMYA değişkenlerinin ham petrol fiyatlarından değişkenlerden gelen şoklara ${ }^{3}$ verdiği tepkiler sergilenmektedir.

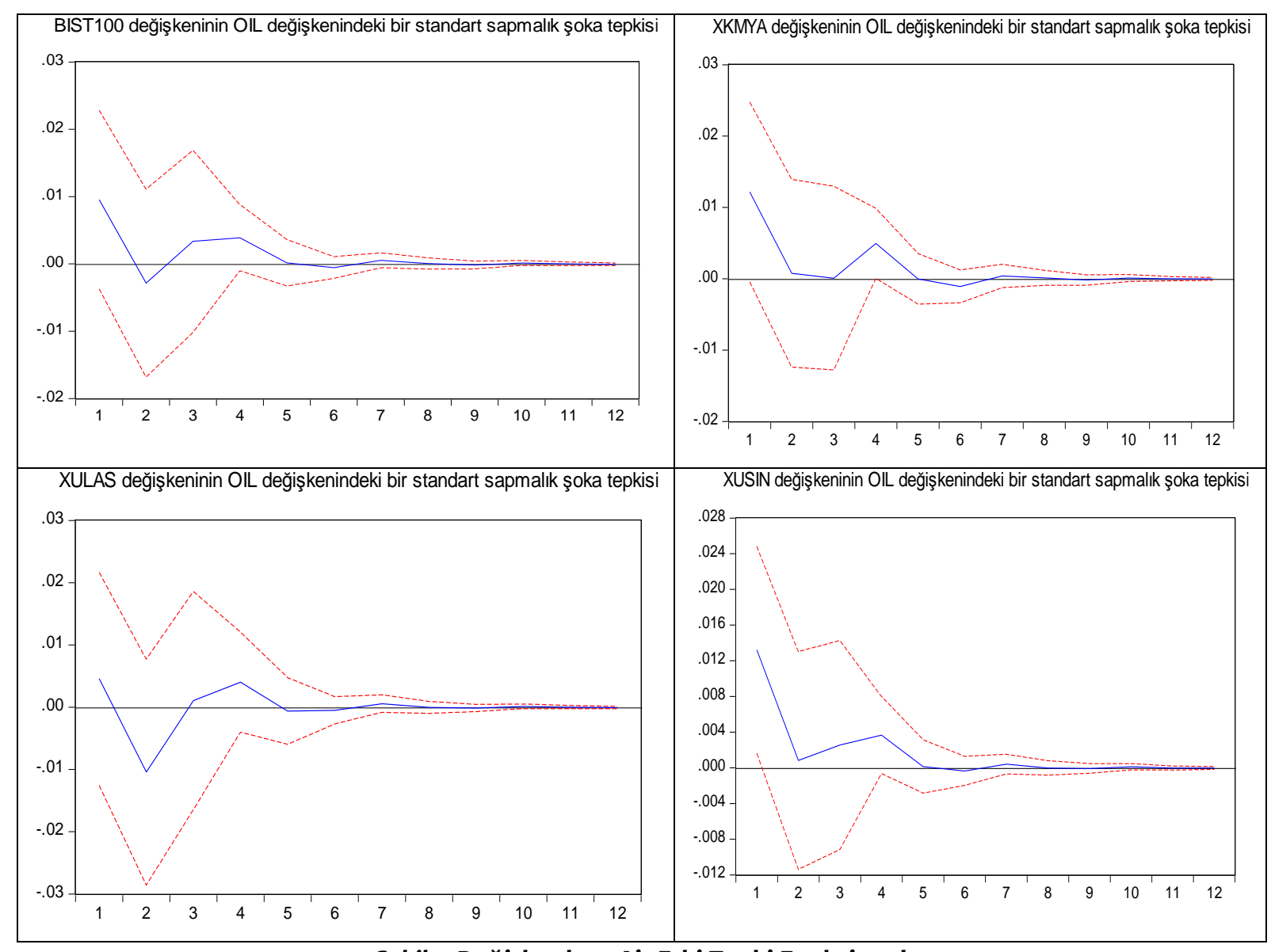

Şekil 1. Değișkenlere Ait Etki Tepki Fonksiyonları

BİST 100 endeks getirilerinin petrol fiyatlarında meydana gelen şoklara verdiği tepki ilk ayda pozitif iken 2.ayda negatife ve 3.ayda tekrara pozitife dönmektedir. Beşinci aydan sonra etki tamamen ortadan kalkmaktadır. XKMYA değişkeninin petrol fiyatlarında meydana gelen şoklara verdiği tepki ilk 5 ay pozitif iken, 5.aydan sonra tepki ortadan kalkmaktadır. XULAS değişkeninin verdiği tepki ilk pozitif daha sonra negatif olmaktadır ve beşinci ayda sonra etki kaybolmaktadır. Benzer şekilde XUSIN değişkeninin petrol fiyatlarında meydana gelen şoklara verdiği tepki ilk 5 ayda pozitiftir ve 5.aydan sonra etki kaybolmaktadır. Burada dikkat edilmesi gereken husus tüm endeks getirilerinin petrol fiyatlarında meydana gelen şoklara verdiği tepki 5.aydan sonra ortadan kalkmaktadır. XKMYA ve XUSIN değişkenleri ilk beş ay boyunca pozitif tepki vermektedir. BİST 100 ve XULAS

\footnotetext{
${ }^{3}$ Bağımlı değişkenlerin analize dahil edilen diğer makroekonomik değişkenlerde meydana gelen şoklara verdiği tepkileri gösteren şekiller EK kısmında yer almaktadır.
} 
değişkenlerinin verdikleri tepki ise benzemekte olup, ilk ayda pozitif sonra negatiften tekrar pozitife döndüğü görülmektedir.

\subsubsection{Varyans Ayrıştırması}

Varyans ayrıştırması, içsel değişkenlerden birindeki değişimi, kendisi dahil tüm içsel değişkenleri etkileyen ayrı ayrı şoklar olarak ayırmakta, böylece sistemin dinamik yapısı hakkında bilgi sahibi olunmaktadır. Analize dahil edilen borsa endeks getirilerinin ham petrol fiyatlarındaki ve diğer bağımsız değişkenlerdeki bir standart sapmalık şoklara verdiği tepki 12 dönem için test edilmiştir.

Öncelikle BİST100 ulusal endeks getirisi değişkenine ait varyans ayrıştırması sonuçlarına bakıldığında (Tablo 6) söz konusu değişkeni en çok açıklayan değişkenlerin kendisi ve reel efektif döviz kuru değişkeni olduğu görülmektedir. BİST 100 değişkeninin kendi kendini açıklama oranı ilk ayda \%84 iken, reel efektif döviz kuru değişkeninin açıklama gücü ise \%14'tür. İlk aydan sonra reel efektif döviz kurunun açıklama oranı yaklaşık \%13 civarında sabitlenmiştir. 3.aydan sonra BíST100 değişkenini açıklamada enflasyon değişkeninin açılama gücü \%4 olduğu görülmektedir. Petrol fiyatları BİST100 değişkenini açıklamada çok önemsiz bir paya sahiptir. Benzer şekilde sanayi üretim endeksi ve faiz oranlarının da payı çok düşüktür.

Tablo 6. BiST10o Değişkenine Ait Varyans Ayrıştırma Sonuçları

\begin{tabular}{cccccccc}
\hline Dönem & S.E. & OP & IP & CPI & REER & IR & BIST100 \\
\hline 1 & 0.0858 & 1.0960 & 0.1109 & 0.1799 & 14.3248 & 0.2592 & 84.0288 \\
2 & 0.0903 & 1.1332 & 1.3866 & 1.6358 & 13.5999 & 2.2410 & 80.0031 \\
3 & 0.0913 & 1.2375 & 1.3617 & 3.2438 & 13.4409 & 2.2064 & 78.5094 \\
4 & 0.0918 & 1.3901 & 1.3486 & 4.0920 & 13.3439 & 2.1989 & 77.6263 \\
5 & 0.0918 & 1.3887 & 1.3482 & 4.1807 & 13.3355 & 2.2073 & 77.5393 \\
6 & 0.0919 & 1.3890 & 1.3729 & 4.3222 & 13.3337 & 2.2071 & 77.3748 \\
7 & 0.0919 & 1.3908 & 1.4338 & 4.3191 & 13.3239 & 2.2090 & 77.3230 \\
8 & 0.0919 & 1.3902 & 1.4429 & 4.3441 & 13.3218 & 2.2085 & 77.2922 \\
9 & 0.0919 & 1.3903 & 1.4455 & 4.3513 & 13.3208 & 2.2091 & 77.2826 \\
10 & 0.0919 & 1.3904 & 1.4534 & 4.3511 & 13.3196 & 2.2094 & 77.2758 \\
11 & 0.0919 & 1.3903 & 1.4555 & 4.3532 & 13.3191 & 2.2093 & 77.2723 \\
12 & 0.0919 & 1.3903 & 1.4555 & 4.3540 & 13.3190 & 2.2094 & 77.2714
\end{tabular}

XULAS değişkenine ait varyans ayrıştırması sonuçlarına bakıldığında (Tablo 7 ) 12 dönem boyunca en çok kendi değişimlerinden ve BİST 100 değişkeninden etkilendiği görülmektedir. Nitekim söz konusu değişkenin ilk aylarda kendini açıklama oranı \%45 ve BİST100 değişkeninin açıklama oranı ise \%40’tır. BİST 100 değişkeni ile benzer şekilde en çok reel efektif döviz kurunun açıklama oranı diğer bağımsız değişkenlere göre daha yüksektir. Enflasyon ve faiz oranı değişkenlerinin açıklama gücü sırasıyla $\% 6$ ve \%3,5 olarak sabitlendiği görülmektedir. Petrol fiyatlarının açıklama gücü sıfıra çok yakındır dolayısıyla önemsizdir. 
Tablo 7. XULAS Değişkenine Ait Varyans Ayrıştırma Sonuçları

\begin{tabular}{ccccccccc}
\hline Dönem & S.E. & OP & IP & CPI & REER & IR & BIST100 & XULAS \\
\hline 1 & 0.0849 & 0.1520 & 0.2393 & 0.1506 & 9.6505 & 0.6399 & 43.5004 & 45.6669 \\
2 & 0.0907 & 0.8708 & 0.3696 & 3.2206 & 9.0156 & 3.5097 & 40.2860 & 42.7272 \\
3 & 0.0920 & 0.8542 & 0.7789 & 5.0859 & 8.9061 & 3.5025 & 39.3136 & 41.5583 \\
4 & 0.0923 & 0.9463 & 0.8824 & 6.0950 & 8.8174 & 3.4696 & 38.7886 & 41.0003 \\
5 & 0.0924 & 0.9484 & 0.8856 & 6.0999 & 8.8137 & 3.4717 & 38.7720 & 41.0084 \\
6 & 0.0925 & 0.9485 & 0.8847 & 6.2062 & 8.8155 & 3.4815 & 38.7191 & 40.9442 \\
7 & 0.0925 & 0.9504 & 0.8949 & 6.2085 & 8.8138 & 3.4854 & 38.7112 & 40.9354 \\
8 & 0.0925 & 0.9503 & 0.8991 & 6.2149 & 8.8139 & 3.4849 & 38.7070 & 40.9295 \\
9 & 0.0925 & 0.9503 & 0.8993 & 6.2184 & 8.8137 & 3.4848 & 38.7054 & 40.9278 \\
10 & 0.0925 & 0.9504 & 0.9011 & 6.2182 & 8.8136 & 3.4848 & 38.7046 & 40.9269 \\
11 & 0.0925 & 0.9504 & 0.9018 & 6.2188 & 8.8135 & 3.4848 & 38.7042 & 40.9263 \\
12 & 0.0925 & 0.9504 & 0.9018 & 6.2191 & 8.8134 & 3.4848 & 38.7041 & 40.9261
\end{tabular}

XKMYA değiş̧kenine ait varyans ayrıştırması sonuçlarına bakıldığında (Tablo 8) kendi dinamiklerinden daha çok BİST 100 değişkeni tarafından açıklanmaktadır. İlk ayda BİST 100 değişkenin söz konusu değişkeni açıklama gücü \%63 iken ilerleyen aylarda \%57 olarak sabitlenmiştir. Petrol fiyatlarının açıklama gücü BİST100 ve XULAS değişkenlerini açıklama gücünden biraz daha yüksek olduğu (\%2) olduğu görülmektedir. Bununla birlikte ilerleyen aylarda bağımsız değişkenlerin açılama gücü sırasıyla; reel efektif döviz kuru (\%7), enflasyon oranı $\% 4,5$ ve faiz oranı $(\% 2,5)$ 'tur.

Tablo 8. XKMYA Değişkenine Ait Varyans Ayrıștırma Sonuçları

\begin{tabular}{ccccccccc}
\hline Dönem & S.E. & OIL & IP & CPI & REER & IR & BIST100 & XKMYA \\
\hline 1 & 0.0854 & 1.9659 & 0.0122 & 0.0001 & 7.1569 & 0.8920 & 63.3863 & 26.5863 \\
2 & 0.0901 & 1.8988 & 0.8139 & 1.2807 & 6.8959 & 2.3589 & 60.9861 & 25.7653 \\
3 & 0.0917 & 1.8364 & 1.0509 & 3.0781 & 7.4540 & 2.3057 & 59.3448 & 24.9298 \\
4 & 0.0922 & 2.0997 & 1.1908 & 3.9216 & 7.6695 & 2.2652 & 58.3275 & 24.5252 \\
5 & 0.0923 & 2.0865 & 1.3983 & 4.1830 & 7.6316 & 2.3314 & 57.9677 & 24.4012 \\
6 & 0.0924 & 2.0913 & 1.3966 & 4.4799 & 7.6495 & 2.3240 & 57.7528 & 24.3056 \\
7 & 0.0924 & 2.0903 & 1.5119 & 4.4742 & 7.6411 & 2.3212 & 57.6790 & 24.2820 \\
8 & 0.0924 & 2.0882 & 1.5473 & 4.5167 & 7.6389 & 2.3188 & 57.6288 & 24.2610 \\
9 & 0.0924 & 2.0881 & 1.5472 & 4.5294 & 7.6409 & 2.3191 & 57.6194 & 24.2555 \\
10 & 0.0924 & 2.0880 & 1.5548 & 4.5290 & 7.6401 & 2.3201 & 57.6134 & 24.2542 \\
11 & 0.0924 & 2.0879 & 1.5577 & 4.5307 & 7.6400 & 2.3201 & 57.6105 & 24.2527 \\
12 & 0.0924 & 2.0878 & 1.5577 & 4.5313 & 7.6401 & 2.3201 & 57.6101 & 24.2525
\end{tabular}

XUSIN değişkenine ait varyans ayrıştırması sonuçlarına bakıldığında (Tablo 9) söz konusu değişkeni en çok açıklayan değişken BİST 100 olup, açıklama gücü ilk ayda \%75 iken, ilerleyen aylarda \%69 olarak sabitlendiği görülmektedir. Bağımsız değişkenlerden gene en çok açıklayan değişken sırasıyla reel efektif döviz kuru, enflasyon oranı ve faiz oranıdır. Petrol fiyatlarının XUSIN değişkenini açıklama gücü diğer sektör endekslerini açıklama gücüne göre daha yüksektir fakat önemsiz denecek kadar düşüktür. 
Tablo 9. XUSIN Değişkenine Ait Varyans Ayrıștırma Sonuçları

\begin{tabular}{ccccccccc}
\hline Dönem & S.E. & OIL & IP & CPI & REER & IR & BIST100 & XUSIN \\
\hline 1 & 0.0847 & 2.7303 & 0.0299 & 0.0036 & 9.1888 & 1.1340 & 75.7582 & 11.1550 \\
2 & 0.0899 & 2.6098 & 1.1077 & 1.6026 & 8.7647 & 3.0548 & 72.2046 & 10.6555 \\
3 & 0.0916 & 2.6644 & 1.2256 & 2.8559 & 8.6676 & 3.0088 & 71.0679 & 10.5094 \\
4 & 0.0922 & 2.8240 & 1.2778 & 3.6191 & 8.7474 & 2.9873 & 70.1583 & 10.3857 \\
5 & 0.0922 & 2.8171 & 1.3480 & 3.7093 & 8.7275 & 3.0267 & 69.9809 & 10.3902 \\
6 & 0.0923 & 2.8114 & 1.3563 & 3.8825 & 8.7447 & 3.0189 & 69.8230 & 10.3629 \\
7 & 0.0923 & 2.8110 & 1.4409 & 3.8788 & 8.7366 & 3.0161 & 69.7589 & 10.3573 \\
8 & 0.0924 & 2.8090 & 1.4674 & 3.9019 & 8.7368 & 3.0140 & 69.7201 & 10.3505 \\
9 & 0.0924 & 2.8087 & 1.4673 & 3.9122 & 8.7370 & 3.0145 & 69.7106 & 10.3494 \\
10 & 0.0924 & 2.8086 & 1.4732 & 3.9120 & 8.7363 & 3.0155 & 69.7050 & 10.3492 \\
11 & 0.0924 & 2.8085 & 1.4763 & 3.9132 & 8.7360 & 3.0154 & 69.7017 & 10.3486 \\
12 & 0.0924 & 2.8084 & 1.4764 & 3.9142 & 8.7360 & 3.0155 & 69.7007 & 10.3485
\end{tabular}

\section{Sonuç}

Türkiye petrol ihtiyacının yaklaşık \%90'dan fazlasını dış ülkelerden ithal etmektedir. Dolayısıyla petrol fiyatlarındaki değişimin Türkiye ekonomisi için etkilerinin araştırılması son derece önemlidir. Petrol fiyatları ile makroekonomik değişkenler ve borsa arasındaki ilişkiyi Türkiye için araştıran çok sayıda çalışma mevcuttur. Petrol fiyatları ile BİST ve BİST sektörel endeksleri arasındaki ilişkiyi araştıran çalışmaların çoğunda Eşbütünleşme ve Granger nedensellik analizi kullanılmıştır. Söz konusu çalışmalar sonuçları bakımından bir birinden farklılık göstermekte olup, bazı çalışmalarda petrol fiyatları ve BİST endeks getirileri arasında uzun ve kısa dönem ilişkisi tespit edilirken, bazılarında ilişkinin olmadığı savunulmaktadır.

$\mathrm{Bu}$ çalışmada petrol fiyatlarındaki değişimlerin BİST 100 ulusal endeksi ve petrol ile yakından ilişsisi bulunan 3 adet sektörel endeks (XULAS, XKMYA ve XUSIN) getirileri arasındaki ilişki VAR yöntemine dayalı etki tepki fonksuyonları ve varyans ayrıştırması kapsamında analiz edilmiştir. Bulgulara göre petrol fiyat değişimlerinin etkisi sektörlere göre değişmektedir.

Etki tepki fonksiyonlarına bakıldığında petrol fiyatlarında meydana gelen şoklara XKMYA ve XUSIN endeks getirileri ilk beş ay boyunca pozitif tepki vermektedir. BİST 100 ve XULAS değişkenlerinin verdikleri tepki ise benzemekte olup, ilk ayda pozitif sonra negatiften tekrar pozitife döndüğü görülmektedir. Bununla birlikte tüm endeks getirilerinin petrol fiyatlarında meydana gelen şoklara verdiği tepki 5.aydan sonra ortadan kalkmaktadır.

Endeks getirilerindeki toplam değişimin ne kadarının petrol fiyatlarındaki ve diğer makroekonomik değişkenlerdeki değiş̧imler tarafından açıklandığı öngörü hata varyans ayrıştırması ile ortaya koyulmuştur. Varyans ayrıştırma sonuçlarına göre BİST100 ulusal endeks getirisi değişkenini en çok kendisi (\%84) ve reel efektif döviz kuru değişkeni (\%14) açıklamaktadır. Petrol fiyatları BİST100 değişkenini açıklamada çok önemsiz bir paya sahiptir. Benzer şekilde sanayi üretim endeksi ve faiz oranlarının da payı çok düşüktür. 
XULAS, XKMYA ve XUSIN endeks getirilerindeki değişimleri en çok açıklayan değişkenin BİST 100 olduğu ve kendi değerleri olduğu görülmüştür. Benzer şekilde makroekonomik değişkenlerden reel efektif döviz kuru endeks getirileri diğer değişkenlere göre daha fazla açıklamaktadır. Petrol fiyatlarındaki değişimlerin söz konusu endeks getirilerini açıklamakta çok önemsiz payı bulunmaktadır. Bu sonuçlar BİST 100 ve sektörel endeks getirilerinin döviz kurundan çok etkilendiğini göstermektedir. Dolayısıyla borsa yatırımcıları yatırım kararlarında en çok döviz kuruna dikkat etmeleri gerekmektedir. 


\section{Kaynakça}

Abdioğlu, Z. ve Değirmenci, N. (2014). "Petrol Fiyatları-Hisse Senedi Fiyatları İlişkisi: BIST Sektörel Analiz”, Kafkas Üniversitesi İktisadi ve İdari Bilimler Fakültesi Dergisi, 5(8).

Arouri, M. E. H. (2011). "Does Crude Oil Move Stock Markets in Europe? A Sector Investigation”, Economic Modelling, 28(4), s.1716-1725.

Basher, S. A. ve Sadorsky, P. (2006). "Oil Price Risk and Emerging Stock Markets", Global finance journal, 17(2), s.224-251.

Basher, S. A., Haug, A. A. ve Sadorsky, P. (2012). "Oil Prices, Exchange Rates and Emerging Stock Markets", Energy Economics, 34(1), s.227-240.

Burbidge, J. ve Harrison, A. (1984). T"esting for The Effects of Oil-Price Rises Using Vector Autoregressions", International Economic Review, s.459-484.

Büberkökü, Ö.(2017). "Çoklu Yapısal Kırılmalar Altında Petrol Fiyatlarının Türk Hisse Senedi Piyasaları Üzerindeki Etkisinin İncelenmesi”, Bankacıllk ve Sermaye Piyasası Araştırmaları Dergisi 1(3), s.15-32

Çelik, İ., Özdemir, A. ve Gülcan, N. (2015). "Petrol Fiyat Dalgalanmalarının Getiri Oynaklığı Üzerine Etkisi: Türkiye'de Alt Endeksler Üzerine Bir Uygulama”, Muhasebe ve Finansman Dergisi, (67), s.157-170.

Dagher, L. ve El Hariri, S. (2013). "The Impact of Global Oil Price Shocks on The Lebanese Stock Market", Energy, 63, s.366-374.

Degiannakis, S., Filis, G. ve Floros, C. (2013). "Oil and Stock Returns: Evidence From European Industrial Sector Indices in a Time-Varying Environment", Journal of International Financial Markets, Institutions and Money, 26, s.175-191.

Faff, R. W. ve Brailsford, T. J. (1999). "Oil Price Risk and The Australian Stock Market”, Journal of Energy Finance \& Development, 4(1), s.69-87.

Gisser, M. ve Goodwin, T. H. (1986). "Crude Oil and The Macroeconomy: Tests of Some Popular Notions: Note". Journal of Money, Credit and Banking, 18(1), s.95-103.

Gönüllü, Ç. O., Otluoğlu, E. Ve Şengöz, M. H. (2015). "Ham Petrol Fiyatı Değişimlerinin Petrokimya Sektörü Getirileri Üzerindeki Etkisi”, Uluslararası Íktisadi ve İdari İncelemeler Dergisi, (14).

Güler, S. ve Temel Nalın, H. (2013). "Petrol Fiyatlarının IMKB Endeksleri Üzerindeki Etkisi”, International Journal of Economic \& Social Research, 9(2). s.79-97

Güler, S., Tunç, R. ve Orçun, Ç. (2010). "Petrol Fiyat Riski ve Hisse Senedi Fiyatları Arasındaki İlişkinin Belirlenmesi: Türkiye'de Enerji Sektörü Üzerinde Bir Uygulama”, Atatürk Üniversitesi İktisadi ve İdari Bilimler Dergisi, 24(4), s.297-315.

Hamilton, J. D. (1983). “Oil and The Macroeconomy Since World War II”, Journal of political economy, 91(2), s.228-248.

Huang, R. D., Masulis, R. W. ve Stoll, H. R. (1996). "Energy Shocks and Financial Markets", Journal of Futures Markets: Futures, Options, and Other Derivative Products, 16(1), s.1-27.

Jones, C. M. ve Kaul, G. (1996). "Oil and The Stock Markets”, The journal of Finance, 51(2), s.463-491.

Kaya, A. ve Binici, Ö. (2014). "BIST Kimya, Petrol, Plastik Endeksi Hisse Senedi Fiyatları İle Petrol Fiyatları Arasındaki İlişkinin İncelenmesi”, Cumhuriyet Üniversitesi İktisadi ve İdari Bilimler Dergisi, 15(1), s.383-395. 
Kendirli, S. ve Çankaya, M. (2016). "Ham Petrol Fiyatlarının BİST 100 ve Bist Ulaştırma Endeksleri İle İlişkisi”, Kastamonu Üniversitesi İktisadi ve İdari Bilimler Fakültesi Dergisi, 12(2), 136-141.

Kılıç, C., Bayar, Y. ve Özcan, B. (2014). "Petrol Fiyatlarının Borsa İstanbul Sanayi Fiyat Endeksi Üzerindeki Etkisi”, Катu-İ̧ Dergisi, 125-141.

Li, H. ve Wen, Zh. (2012). "Causal Relation between Macro Economy and Industrial Index Based on Regression Analysis”, Journal of Theoretical and Applied Information Technology, 46(2), s.754-761.

Li, S. F., Zhu, H. M. ve Yu, K. (2012). “Oil Prices and Stock Market in China: A Sector Analysis Using Panel Cointegration with Multiple Breaks”, Energy Economics, 34(6), s.1951-1958.

Nandha, M. ve Faff, R. (2008). "Does Oil Move Equity Prices? A Global View”, Energy Economics, 30(3), s. 986-997.

Narayan, P. K. ve Narayan, S. (2010). “Modelling The Impact of Oil Prices on Vietnam's Stock Prices", Applied energy, 87(1), s.356-361.

Öztürk, M. B., Gümüş, G. K., Taşkın, F. D.ve Çağlı, E. Ç. (2013). "Petrol ve Doğalgaz Fiyatları ile İmalat ve Kimya-Petrol-Plastik Sektörlerinin Endeksleri Arasındaki İlişki”,Ömer Halisdemir Üniversitesi İktisadi ve İdari Bilimler Fakültesi Dergisi, 6(2), s.64-73

Toraman, C., Başarır, Ç. ve Bayramoğlu, M. F. (2011). "Effects of Crude Oil Price Changes on Sector Indices of Istanbul Stock Exchange”. European Journal of Economic \& Political Studies, 4(2).

Yıldırım, M., Bayar, Y. ve Kaya, A. (2014). "Enerji Fiyatlarının Sanayi Sektörü Hisse Senedi Fiyatları Üzerindeki Etkisi: Borsa İstanbul Sanayi Sektörü Şirketleri”. Muhasebe ve Finansman Dergisi, (62), s.93-108. 
EK

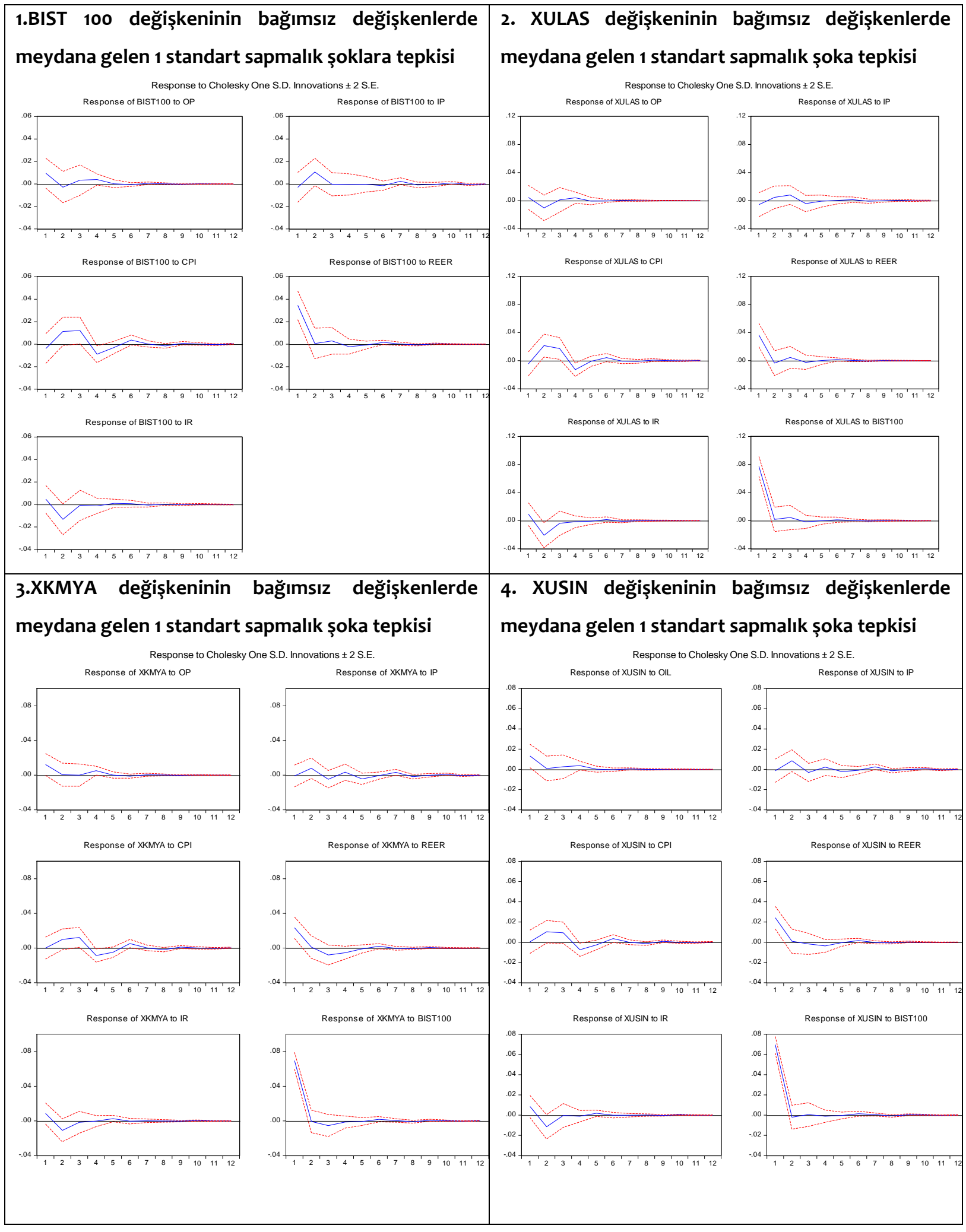

